\title{
KAKO PRIPOMOČI K UČINKOVITEJŠEMU UČENJU IN SPREMINJANJU ŽIVLJENISKEGA SLOGA OSEB S KRONIČNO BOLEZNIJO
}

Doc. dr.

Irena Lesar

Pedagoška fakulteta

Univerze $v$ Ljubljani

\section{POVZETEK}

Ob pojavu kronične bolezni, ki prizadene vsakega šestega od desetih odraslih, je treba poskrbeti tako za zdravstveno urejenost bolezni kot za obvladovanje čustvenih odzivov nanjo (jeza, strah, frustracije, žalost), ne nazadnje pa je treba ohraniti oz. (pre)oblikovati (nove) vloge na delovnem mestu, v družini in med prijatelji. Na poti iskanja primernih strategij obvladovanja kronične bolezni in življenja kroničnega bolnika ima zdravstveno osebje zelo pomembno vlogo. Obolelim bi morali ponuditi kakovostne zdravstvenovzgojne programe, ki se ne osredinjajo le na značilnosti kroničnih bolezni in na možnosti zdravljenja, marveč upoštevajo tudi človeško stisko ob sprejemanju kronične bolezni, pa tudi njen vpliv na preostala področja posameznikovega življenja. Raziskave kažejo, da ima pri vseh teh nalogah za obolelega zelo veliko vlogo sposobnost empatičnega komuniciranja zdravstvenega osebja.

Ključne besede: tradicionalni programi, programi za samovodenje bolezni, strategije obvladovanja, empatična komunikacija, zdravstveno osebje, diabetes, izobraževanje kronično bolnih, izobraževanje odraslih

\section{IMPROVING EFFICACY OF LEARNING AND CHANGING OF LIFESTYLES IN PERSONS WITH CHRONIC DISEASES - ABSTRACT}

In case of appearance of a chronic disease, which affects every sixth in ten adults, it is necessary to provide proper medical treatment as well as to deal with emotional responses to the disease (anger, frustration, sadness) and to control them. It is also necessary for the individual to preserve or transform the roles he plays at work, in the family and among friends. When searching for suitable strategies for control of the disease and one's life, medical staff plays an important role. Patients should be offered quality medical education programs, focusing not only on the characteristics of the chronic disease and treatment options, but also dealing with the anxiety experienced by individuals facing the disease, as well as its impact on other spheres of their lives. Research shows that empathy in the communication of the medical staff with the diseased plays a significant role in all these tasks.

Keywords: traditional programs, disease self-management porograms, control strategies, communication empathy, medical staff, diabetes, patient education in chronic diseases, adult education

\section{UVOD}

V sodobnosti je mogoče opaziti čedalje večji delež ljudi z različnimi kroničnimi boleznimi, kar lahko deloma pripišemo daljši življenjski dobi, bistveno spremenjenemu življenjskemu slogu (pogostejši sedeči način dela, prehrana, gibanje, stres ...), nemajhno vlogo pri povečanju deleža teh bolezni pa ima tudi razvoj medicine in farmacije. V nekaterih deželah naj bi kar šest od desetih odraslih poročalo o kroničnih zdravstvenih težavah (Taylor, Bury, 2007: 30), medtem ko v poročilu Svetovne zdravstvene organizacije o preventivi kroničnih bolezni poudarjajo, da je 35 od 58 milijonov smrti na svetu posledica kroničnih bolezni (Preventing chronic diseases: a vital investment, 2005: 38). Kronične bolezni so torej glavni razlog smrti pri odraslih, število umrlih zaradi tega razloga pa naj bi se v prihodnjih desetih letih povečalo še za 17 
odstotkov (prav tam: 7). Prebivalci Slovenije s kronično boleznijo oz. katero od vrst zmanjšane zmogljivosti delovanja živimo v povprečju sedem let, kar pomeni devet odstotkov celotne pričakovane življenjske dobe (Nadgradnja zdravstvenega sistema do leta 2020, 2011: 12).

Nedvomno so podatki o razširjenosti in trajanju različnih kroničnih bolezni ter o smrtnosti zaradi njih velik razlog za razmislek in načrtovanje ne le primarnih, marveč tudi sekundarnih in terciarnih preventivnih akcij na različnih ravneh družbenega delovanja. V tem kontekstu so zelo pomembni predvsem zdravstvenovzgojni programi za različne skupine (še ne) obolelih ljudi. Načrtovanje zdravstvenovzgojnih programov pri že obolelih, torej terciarne preventive, ${ }^{1}$ je precej zahtevno, saj naj bi se v okviru teh dejavnosti ne odzivali le na zdravstvene težave obolelih, marveč tudi na njihove čustvene, socialne in duhovne potrebe, ki so posledica kronične bolezni. V prispevku bomo prek spoznavanja nalog, s katerimi se spopada posameznik s kronično boleznijo, in strategij obvladovanja kroničnih bolezni ugotavljali, kako bi bilo treba oblikovati in izvajati zdravstvenovzgojne programe, $\mathrm{s}$ katerimi bi se konstruktivno odzvali na potrebe obolelih, in kakšna je pri tem vloga zdravstvenega osebja.

\section{ČLOVEK V PROCESU SPREJEMANIA KRONIČNE BOLEZNI}

$\mathrm{V}$ sodobnem pojmovanju bolezni in zdravja, $\mathrm{v}$ katerem je zdravje imperativ slehernega človeka in bolezen razumljena kot posledica premajhne skrbi zase, neučinkovitih strategij izražanja čustvenih travm ..., ima izkušnja kronične bolezni še veliko kompleksnejše posledice kot nekdaj. Kronična bolezen v posamezniku sproži nemalo zahtevnih vprašanj in razmislek o potrebnih spremembah ustaljenega življenjskega sloga. Za lažje razumevanje zahtevnosti takšnega položa-

Preglednica 1: Primerjava značilnosti akutnih in kroničnih bolezni (povzeto po Holman, Lorig, 2004: 240)

\begin{tabular}{|l|l|}
\hline Značilnosti akutnih bolezni & Značilnosti kroničnih bolezni \\
\hline nenadna pojavnost bolezni & navadno postopen začetek bolezni \\
\hline omejeno trajanje & bolezen se razvija skozi čas \\
\hline običajno posamezen vzrok & multivariantna vzročnost, spreminjanje skozi čas \\
\hline diagnoza in prognoza sta pogosto natančni & diagnoza pogosto negotova, prognoza nejasna \\
\hline samoomejena ali pa so na volio posebne terapije & razgiban in nepredvidliiv potek \\
\hline tehnološki posegi so običajno učinkoviti (laboratorij, & $\begin{array}{l}\text { nedoločeni tehnološki postopki in terapije, privedejo } \\
\text { tudi do dodatnih težav/zapletov }\end{array}$ \\
\hline po ozdravitvi verjetna povrnitev zdravja & $\begin{array}{l}\text { ni ozdravitve, treba se je naučiti obvladovati bolezen } \\
\text { ves čas }\end{array}$ \\
\hline minimalna negotovost & zelo visoka stopnja negotovosti \\
\hline strokovnjaki usposoblieni, laiki neizkušeni & $\begin{array}{l}\text { strokovnjaki in laiki delno in vzajemno (s)pozna(vajo } \\
\text { bolezen }\end{array}$ \\
\hline
\end{tabular}


ja si poglejmo osnovne značilnosti akutnih in kroničnih bolezni (glej Preglednico 1).

Pri kroničnih boleznih so simptomi največkrat stalni, v razvoju bolezni se včasih tudi spreminjajo, in ker ozdravljenje ni pričakovano, je treba poskrbeti za čim boljšo urejenost klinične slike. Zato učinkovita obravnava kroničnih bolezni predpostavlja stalne in različne zdravstvene terapije, oboleli pa morajo veliko vedeti o posledicah svoje kronične bolezni in potrebnih terapijah, ki jih morajo znati uporabljati v svojem življenju. Dobro bi bilo, da bi oboleli razumeli vpliv kronične bolezni na svoje življenje in da bi sprejeli odgovornost za to, kako bo potekalo njihovo nadaljnje (spremenjeno) življenje $\mathrm{z}$ boleznijo, in tudi odgovornost za to, kako bo potekalo njihovo zdravljenje. Za učinkovito in uspešno vodenje bolezni je med obolelimi in zdravstvenim osebjem torej nujno prenašati in dopolnjevati spoznanja o poteku kronične bolezni in nositi skupno odgovornost za ohranjanje čim manj ogrožajočega zdravstvenega stanja (Holman, Lorig, 2004: 239-240).

Pred človeka, ki se spopada s kronično boleznijo, so torej postavljene nove, precej težke naloge, ki pa niso povezane le $\mathrm{z}$ vidikom urejenosti bolezni. Že leta 1988 sta Corbin in Strauss razmejila tri sklope nalog, ki čakajo ljudi s kroničnimi boleznimi. To so:

- zdravstvena urejenost bolezni (jemanje zdravil, sprememba prehranjevanja in gibanja, samostojno merjenje krvnega sladkorja ...);

- oblikovanje in ohranjanje novih smiselnih vlog na delovnem mestu, v družini, med prijatelji;

- ozaveščanje in obvladovanje svoje jeze, strahu, frustracij in žalosti zaradi kronične bolezni (Bodenheimer, Lorig, Holman, Grumbach, 2002: 2471).
Kot ugotavljajo nekateri avtorji, vsakdo ni sposoben vključiti kronične bolezni v svoje življenje oz. se načini odzivanja na situacijo precej razlikujejo. Proučevane razlike se nanašajo na to, kako obolelim kljub bolezni uspeva ohranjati svoje dosedanje socialno življenje in kako jim uspe vključiti bolezen v svoje sebstvo. Upoštevajoč ta dva vidika, zasledimo štiri tipe odnosa do bolezni, ki jih razvijejo posamezniki s kronično boleznijo. To so:

- aktivno zanikanje (ne sprejmejo svoje bolezni, trudijo se ohranjati nekdanji oz. svoj običajni slog življenja),

- prilagoditev oz. akomodacija (sprejmejo svojo bolezen in ustrezno spremenijo svoje dotedanje življenje in delo),

- $\quad$ sekundarna prilagoditev (sprejmejo svojo bolezen in omejitve, toda zaradi bolezni izstopijo iz svojega dotedanjega socialnega življenja) in

- resignacija (bolezen doživijo kot rušilno dejstvo, saj zanje pomeni veliko izgubo življenjskih priložnosti in izkušenj) (Radley, 1995, v Ule, 2003: 93-94).

Spremembe, ki v življenju človeka nastopijo zaradi njegove kronične bolezni, lahko v nekaterih posameznikih spodbudijo prepričanje, da prvič v življenju obvladujejo življenje, in jim omogočijo doživljanje celo bolj kakovostnega življenja kot pred boleznijo, lahko pa pri drugih vodijo v popolno resignacijo (Ule, 2003: 91, 94). Za čim lažje sprejemanje bolezni v svoje življenje in tudi uvajanje potrebnih sprememb prejšnjega življenjskega sloga naj bi, po ugotovitvah K. Charmaz (2000: 280), posameznik obvladal predvsem tri strategije: (a) kljub stalnosti simptomov oz. kronične bolezni zmogel najti smisel v življenju, (b) rekonstruiral red v svojem življenjskem svetu, tako da bo zmogel shajati s svojo boleznijo, 
(c) vzdrževati nadzor nad konkretnimi vsakodnevnimi dejavnostmi, s čimer oboleli spet pridobi kontinuiteto ter skladnost samega sebe in svojega sveta.

»Tisto, kar je boleče pri kronični bolezni, niso samo in predvsem nove življenjske ovire in težave, ampak občutek popolne drugačnosti, izvzetosti, kar lahko vodi v sekundarno prostovoljno izolacijo in osamitev. Pogosta posledica kronične bolezni je občutek prikrajšanosti, občutek krivičnosti življenja. 'Sedenje v istem čolnu' lahko zelo omili te občutke in zmanjša občutek stigmatizacije.« (Ule, 2003: 86-87) Glede na navedeno je zelo dobrodošlo, da imajo oboleli možnost prenašanja izkušenj življenja s kronično boleznijo drug na drugega (npr. v društvih, skupinah za samopomoč), kar jim pomaga pri prepoznavanju zanje sprejemljivih strategij obvladovanja bolezni. K. Charmaz (2000: 284) ugotavlja, da so predvsem mlajši posamezniki s kronično boleznijo pravi inovatorji v strategijah obvladovanja bolezni. Pomagajo si z novimi tehnologijami - z virtualnim mreženjem vzpostavljajo in ohranjajo stike $\mathrm{z}$ drugimi obolelimi, $\mathrm{z}$ njimi komunicirajo, si izmenjujejo izkušnje in informacije itd. Nekateri med njimi razvijejo tako inovativne načine spoprijemanja s svojo boleznijo, da presenetijo celo zdravstveno osebje.

Človek s kronično boleznijo potrebuje torej stalno zdravstveno podporo in temeljito spremembo načina življenja (prehrana, gibanje, prosti čas ...), socialnih ter neredko tudi delovnih okoliščin, saj bolezen spremlja precejšen čustveni pritisk (stres). $\mathrm{V}$ tem procesu imajo izjemno pomembno vlogo najbližji in zdravstveno osebje, saj se kakovostne spremembe lahko zgodijo le v komunikaciji obolelega $\mathrm{z}$ njemu pomembnimi osebami.

\section{MOŽNI ODZIVI ZDRAVSTVENEGA OSEBJA OB SPOPADANJU ČLOVEKA S KRONIČNO BOLEZNIJO}

$\mathrm{Na}$ podlagi doslej navedenega lahko ugotovimo, da bi morala biti naloga zdravstvenega osebja ne le skrbeti za zdravstveno urejenost kronične bolezni, marveč bi morali biti pripravljeni vzeti si čas in biti v podporo tudi ob posameznikovih čustvenih, socialnih in duhovnih potrebah, ki so posledica kronične bolezni. Pa si poglejmo, kako so se zdravstveni delavci, ki se srečujejo s posamezniki s kroničnimi boleznimi, doslej (večinoma) odzivali na prepoznane potrebe.

Tradicionalni pogled zdravnikov in drugega zdravstvenega osebja na obolele (glej Preglednico 2) izhaja iz pozicije moči, saj sebe zaznavajo kot strokovnjake, ki s svojim strokovnim znanjem pomagajo obolelemu v procesu zdravljenja. Toda pri kroničnih boleznih nastaja nova paradigma odnosa obolelega z ljudmi, ki mu ob sprejemanju in vključevanju bolezni $\mathrm{v}$ svoje življenje lahko le pomagajo, saj ozdravljenje ni mogoče. Zato bi zdravstveni delavci morali postati sogovorniki (svetovalci) obolelemu in naj bi mu ponujali zlasti strokovno pa tudi čustveno podporo, nikakor pa se $\mathrm{v}$ odnosu ne bi več smeli postavljati kot absolutni poznavalci poteka in zdravljenja bolezni, ki bi bili v tem kontekstu zmožni oblikovanja konkretnih rešitev za posameznika. Ta partnerska paradigma vključuje dva pomembna elementa: skupno skrb za urejanje kronične bolezne oz. sodelovanje obolelega in zdravstvenega osebja pri skrbi za urejanje bolezni ter zdravstvenovzgojni proces, ki podpira samovodenje kronične bolezni. Sodelovanje v tej skrbi zahteva skupno odločanje obolelega, ki je »strokovnjak« za svoje življenje, in zdravstvenih delavcev, ki so strokovnjaki za 
posamezne bolezni. Rezultati ene od študij (Bodenheimer, Lorig, Holman, Grumbach, 2002: 2471) pa kažejo, da je bilo skupno odločanje zdravstvenega osebja in obolelega opaziti le $\mathrm{v}$ eni četrtini od vseh $\mathrm{v}$ raziskavo zajetih vizit.

Primerjava tradicionalne skrbi za obolele in sodobne, na partnerskem odnosu temelječe skrbi kaže na jasne razlike $\mathrm{v}$ razmerju med obolelim in zdravstvenim osebjem, ki zahtevajo novo opredeljevanje vlog. Izhajati iz problemov, ki jih zaznavajo posamezniki s kronično boleznijo, pomeni, da z obolelimi vzpostavimo spoštljiv odnos, da omogočimo iskren dialog in da skupaj iščemo rešitve za njihove težave. Ta na videz majhna sprememba $v$ realnosti pomeni, da zdravstveno osebje v odnos z obolelim ne vstopa le v vlogi strokovnjaka za neko bolezen, ampak zlasti kot ljudje, ki razumejo posameznikovo trpljenje in sprejemajo dejstvo, da kronična bolezen v življenje obolelega prinese psihično, predvsem čustveno neravnovesje, ki vpliva na njegovo delovanje in kakovost življenja. Donaldson (2003: 1-2 ) poudarja, da bo resnično

Preglednica 2: Primerjava tradicionalne in partnerske skrbi pri kroničnih boleznih (Bodenheimer, Lorig, Holman, Grumbach, 2002: 2470)

\begin{tabular}{|c|c|c|}
\hline Problem/tema & Tradicionalna skrb & Partnerska skrb \\
\hline $\begin{array}{l}\text { Kakšni so odnosi med } \\
\text { obolelim in zdravstvenim } \\
\text { osebjem? }\end{array}$ & $\begin{array}{l}\text { Zdravstveni delavci so strokovnjaki, } \\
\text { ki povedo obolelemu, kaj mora } \\
\text { storiti. Oboleli je pasiven. }\end{array}$ & $\begin{array}{l}\text { Skupno strokovno znanje z aktivno- } \\
\text { stjo obolelega. Zdravstveni delavci } \\
\text { so strokovnjaki za bolezen in obole- } \\
\text { li je strokovnjak za svoje življenje. }\end{array}$ \\
\hline $\begin{array}{l}\text { Kdo je glavni skrbnik in reše- } \\
\text { valec težav? Kdo je odgovo- } \\
\text { ren za rezultate? }\end{array}$ & Zdravstveno osebje. & $\begin{array}{l}\text { Zdravstveno osebje in oboleli so } \\
\text { glavni skrbniki; delijo si odgo- } \\
\text { vornost za reševanje težav in za } \\
\text { rezultate. }\end{array}$ \\
\hline Kai je cili? & $\begin{array}{l}\text { Izpolnjevanje navodil. Neizpol- } \\
\text { njevanje navodil je individualni } \\
\text { primanjkljaj obolelega. }\end{array}$ & $\begin{array}{l}\text { Oboleli določa cilje in zdravstveno } \\
\text { osebje pomaga obolelemu pri } \\
\text { sprejemanju utemeljenih odločitev. } \\
\text { Nedoseganje zastavljenih ciljev } \\
\text { je težava, ki jo je treba reševati s } \\
\text { prilagojenimi strategijami. }\end{array}$ \\
\hline $\begin{array}{l}\text { Kako se spreminja vedenje/ } \\
\text { ravnanje? }\end{array}$ & Zunanja motivacija. & $\begin{array}{l}\text { Notranja motivacija. Oboleli } \\
\text { pridobi razumevanje in samozavest } \\
\text { (samozaupanje) za doseganje } \\
\text { zaželenega vedenja. }\end{array}$ \\
\hline Kdo opredeli težave? & $\begin{array}{l}\text { Zdravstveno osebje, t. j. nujna spre- } \\
\text { memba nezdravih oblik vedenja. }\end{array}$ & $\begin{array}{l}\text { Oboleli, t. j. njegova (fizična in/ali } \\
\text { psihična) bolečina ali nesposobnost } \\
\text { delovanja, pa tudi zdravstveno } \\
\text { osebje. }\end{array}$ \\
\hline Kako se težave rešujejo? & $\begin{array}{l}\text { Zdravstveno osebje rešuje težave } \\
\text { obolelega. }\end{array}$ & $\begin{array}{l}\text { Zdravstveno osebje obolelega uči } \\
\text { spretnosti reševanja težav in mu tudi } \\
\text { pomaga pri reševanju težav. }\end{array}$ \\
\hline
\end{tabular}


partnerstvo med zdravstvenim osebjem in obolelim doseženo le, če se bodo zgodile pomembne spremembe $\mathrm{v}$ njihovih predstavah o svojih vlogah v medsebojnih odnosih.

V partnerskem konceptu skrbi za vodenje bolezni je v ospredju »opolnomočenje obolelega«, saj naj bi bil poudarek na spodbujanju obolelega, da v okviru svojih možnosti sprejme odgovornost za upravljanje svojega življenja. Obolele zato spodbujajo, da svoje težave rešujejo sami, vendar s podporo zdravstvenega osebja (Bodenheimer, Lorig, Holman, Grumbach, 2002: 2470). Pomembno je torej obolele usposobiti za samovodenje kronične bolezni (Bury, Newbould, Taylor, 2005; Donaldson, 2003; Holman, Lorig, 2004; Townsend, 2011), pri čemer pa se postavlja vprašanje, kdo je odgovoren za to: ali je to stvar obolelih samih, ki se združujejo bodisi v prostovoljna društva ${ }^{2}$ bodisi iščejo povsem individualne poti učenja, ali pa zdravstvenega sistema, ki zagotovi vključenost strokovnjakov v program in poskrbi, da program doseže vsakega obolelega posameznika (npr. Taylor, Bury, 2007)? Z vidika pojavnosti kroničnih bolezni in stroškov zaradi nadaljnjih zapletov, ki so posledica slabega uravnavanja bolezni, je več kot jasno, da bo treba v zdravstvenih sistemih izvajanju kakovostnih programov nameniti bistveno več pozornosti.

\section{ZDRAVSTVENOVZGOJNI PROGRAMI IN NIIHOVA UČINKOVITOST}

Glede na pojavnost kroničnih bolezni pri odrasli populaciji je povsem jasno, da večina zdravstvenih sistemov, ki se osredinjajo zlasti na zdravljenje akutnih bolezni (Holman, Lorig, 2004), ne more učinkovito obvladovati vseh zdravstvenih zapletov in težav brez sodelovanja obolelega. Toda za samovodenje bolezni je treba obolele uspo- sobiti, jim posredovati kakovostna znanja in razviti spretnosti, ki jim bodo omogočale aktivno sodelovanje in sprejemanje (so) odgovornosti pri obvladovanju bolezni. Katera znanja, spretnosti in zmožnosti so potrebni za učinkovito samovodenje bolezni?

Tradicionalni zdravstvenovzgojni programi (glej Preglednico 3), ki jih izvajajo zdravstveni delavci, se bolj ali manj osredinjajo na temeljne informacije o bolezni in »tehnične« spretnosti ravnanja s potrebnimi pripomočki (npr. merjenje sladkorja v krvi ...), težave pa prepoznavajo predvsem kot posledico neprimernega nadzora bolezni. Cilj takšnih programov je upoštevanje spremenjenih vzorcev vedenja, ki jih določa zdravstveno osebje in ki bodo pripomogli $\mathrm{k}$ izboljšanju klinične slike bolezni. Programi za samovodenje bolezni, katerih cilj je doseči čim večjo lastno učinkovitost pri izboljšanju klinične slike, pa vključujejo zlasti učenje spretnosti reševanja težav, predvsem tistih, ki jih oboleli pri sebi prepoznavajo kot povezane z njihovo kronično boleznijo. V ozadju teh programov je predpostavka, da večja samozavest obolelih in zaupanje $\mathrm{v}$ lastne sposobnosti za spreminjanje ustaljenih življenjskih vzorcev prinašata boljše klinične rezultate. Ključna posebnost usposabljanja za samovodenje kronične bolezni je kratkoročni akcijski načrt (eno- do dvotedenski), ki ga ob nasvetih zdravstvenega osebja oblikuje oboleli sam (Bodenheimer, Lorig, Holman, Grumbach, 2002: 2471).

Pri sodobnem usposabljanju sta torej pomembna dva elementa: (1) oboleli se najprej nauči spretnosti reševanja težav, kar uporabi pri težavah, ki jih je prepoznal v svojem življenju, in naredi akcijski načrt za njihovo reševanje; in (2) pridobljene spretnosti uporablja v okviru vseh treh vidikov kronične bolezni: medicinskega, družbenega in osebnega (prav tam: 2472). To kaže na potrebo po spremembi vloge zdravstve- 
nega osebja, saj bi morali zdravstveni delavci postati zlasti dobri učitelji, ki zagotavljajo pomoč obolelim pri razvoju strokovno utemeljenega in zdravju bolj naklonjenega sloga življenja, torej takšnega sloga, ki njihovega stanja ne bo programov za samovodenje bolezni kot tradicionalnih programov (Bodenheimer, Lorig, Holman, Grumbach, 2002: 2474; Townsend, 2011), drugi pa so precej skeptični do teh rezultatov oz. do uporabljene metodologije,

Preglednica 3: Značilnosti tradicionalnih programov in programov za samovodenje (Bodenheimer, Lorig, Holman, Grumbach, 2002: 2471)

\begin{tabular}{|c|c|c|}
\hline & TRADICIONALNI PROGRAMI & $\begin{array}{l}\text { PROGRAMI ZA SAMOVODE- } \\
\text { NJE BOLEZNI }\end{array}$ \\
\hline Katero znanje se prenaša? & $\begin{array}{l}\text { Informacije o bolezni in tehnične } \\
\text { spretnosti. }\end{array}$ & Spretnosti reševanja težav. \\
\hline Kako se opredelijo težave? & $\begin{array}{l}\text { Težave so posledica neustreznega } \\
\text { nadzora bolezni. }\end{array}$ & $\begin{array}{l}\text { Oboleli opredeli težave, ki jih } \\
\text { doživlja in ki so povezane z } \\
\text { boleznijo. }\end{array}$ \\
\hline $\begin{array}{l}\text { Kakšno je razmerje med pro- } \\
\text { gramom in boleznijo? }\end{array}$ & Program je specifičen za bolezen. & $\begin{array}{l}\text { Program zagotavlja spretnosti } \\
\text { reševanja težav, ki so relevantne } \\
\text { za posledice kronične bolezni. }\end{array}$ \\
\hline $\begin{array}{l}\text { Na kateri teoriji temelii zdra- } \\
\text { vstvenovzgojni program? }\end{array}$ & $\begin{array}{l}\text { Specifična znanja o bolezni } \\
\text { vplivajo na vedenjske spremembe } \\
\text { obolelih, kar pripomore k boljši } \\
\text { klinični sliki. }\end{array}$ & $\begin{array}{l}\text { Večja samozavest obolelih glede } \\
\text { lastnih zmožnosti spreminjanja } \\
\text { svojega življenja (samoučinkovi- } \\
\text { tost) prinaša boljšo klinično sliko. }\end{array}$ \\
\hline Kai je cili? & $\begin{array}{l}\text { Skladno z zaželenimi vedenjskimi } \\
\text { spremembami poučiti obolele, } \\
\text { kako izboljšati klinično sliko. }\end{array}$ & $\begin{array}{l}\text { Povečati samoučinkovitost, da bi } \\
\text { izboljšali klinično sliko obolelega. }\end{array}$ \\
\hline Kdo izvaja program? & Zdravstveno osebje. & $\begin{array}{l}\text { Zdravstveno osebje, drugi oboleli, } \\
\text { najpogosteje v skupinah. }\end{array}$ \\
\hline
\end{tabular}

poslabševalo (Holman, Lorig, 2004: 240; poudarila I. L.). Pomembna pa je tudi pripravljenost zdravstvenega osebja za skupno odkrivanje novih načinov obvladovanja bolezni, kar pomeni, da bi morali sprejemati tudi vlogo učencev in priznati vlogo učiteljev tudi obolelim.

In kaj kažejo raziskave o učinkovitosti omenjenih dveh pristopov k zdravstvenovzgojnemu delu? Nekateri avtorji poudarjajo, da številne raziskave kažejo na večjo učinkovitost saj se ti progami večinoma izvajajo v okviru prostovoljnih društev in ne dosežejo vseh obolelih (Taylor, Bury, 2007). Ob tem velja omeniti, da so denimo v okviru tradicionalnih zdravstvenovzgojnih programov na področju diabetesa med 46 študijami, ki so merile tudi učinkovitost programov usposabljanja za spretnosti ravnanja $s$ tehničnimi pripomočki, v 33 študijah ugotovili pozitiven vpliv, v 13 pa celo negativnega. $\mathrm{V}$ nasprotju $\mathrm{s}$ tem pa so pri udeležencih programov le $\mathrm{v} 18 \mathrm{od}$ 
54 študij ugotovili boljšo urejenost glikemije (Bodenheimer, Lorig, Holman, Grumbach, 2002: 2472). Te študije nekako izražajo dvom o učinkovitosti tradicionalnih zdravstvenovzgojnih programov oz. kažejo na potrebnost drugačne konceptualizacije teh programov. $\mathrm{V}$ zadnjem desetletju pa tudi pri sladkornih bolnikih izvajajo programe za podporo samovodenja bolezni, ki dosegajo pozitivne rezultate spoprijemanja z boleznijo. Te je mogoče prepoznati $\mathrm{v}$ manj pogosti depresivnosti, ki velikokrat spremlja sladkorne bolnike, v povečanju fizične dejavnosti obolelih idr. (Davis, 2011).

Rezultati nekaterih raziskav o učinkovitosti tradicionalnih zdravstvenovzgojnih programov in sodobnejših programov za samovodenje sladkorne bolezni nas deloma prepričajo, da so programi za samovodenje učinkovitejši. Toda ali je zdravstvena urejenost bolezni lahko edino merilo učinkovitosti programov? Poglejmo si še, kako bi lahko obolele podprli ob osebnih stiskah, ki so posledica kronične bolezni.

\section{KAKO SE ODZVATI NA ČUSTVENE, SOCIALNE IN DUHOVNE STISKE OBOLELIH}

Strategije obvladovanja bolezni, ki med drugim vključujejo tudi obvladovanje simptomov, reden in kakovosten način prehranjevanja, dovolj gibanja in počitka, so izjemno pomembne, toda večini obolelih je najtežje poiskati smisel v svojem nadaljnjem življenju. Viktor Frankl (1987: 122) je že v prejšnjem stoletju poudarjal, da je potrebna tudi zdravniška skrb za dušo obolelega. S to potrebo se ne srečujejo le specialisti, marveč bi nanjo morali znati odgovarjati vsi zdravniki, še posebno takrat, ko imajo pred seboj človeka, ki se mora soočiti $\mathrm{z}$ usodnim in neizogibnim trpljenjem. Homo patiens terja medicus humanus, trpeči človek zahteva humanega zdravnika, ki ne deluje le kot zdravnik, temveč tudi kot človek. ${ }^{3}$ Pri zdravniški skrbi za dušo gre za to, da bi človeka naredili zmožnega prenašati trpljenje vpričo usodnega in nujnega trpljenja. Sposobnost trpljenja pa konec koncev ni nič drugega kot sposobnost uresničevanja vrednot stališča, ${ }^{4}$ kot jih je poimenoval Frankl. Treba pa je poudariti, da o uresničevanju vrednot stališča, torej o osmišljanju življenja (tudi) v trpljenju, začnemo razmišljati šele tedaj, ko je trpljenje neizogibno. $\mathrm{V}$ takšnem trenutku je nujno, da obolelega notranje podpremo, da se nauči sprejeti neizogibno kot resnično usodo. Sprejemanje trpljenja zahteva prevrednotenje dotedanjih vrednot, torej spremembo dotedanje lestvice posameznikovih vrednot. Pri tem je pomembno, da oboleli oblikuje stališča do svoje bolezni in strategije, ki mu omogočajo spoprijemanje $\mathrm{z}$ boleznijo. $\mathrm{Z}$ eno besedo bi lahko rekli, da takrat, ko posameznik svoje bolezni ne more spremeniti, jo mora predvsem sprejeti.

Eden izmed načinov osmišljanja bolezni je narativna rekonstrukcija življenja, ki temelji na preusmeritvi posameznikove življenjske zgodbe (Charmaz, 2000; Kleinman, Seeman, 2000; Ule, 2003). »Vloga naracije je rekonstrukcija življenjskega poteka in umestitev bolezni v normalen življenjski potek, da se s tem ohranja osebna in socialna kompetentnost posameznika. Tu ne gre samo za funkcionalno prilagoditev bolnega telesa na zahteve zdrave družbe in tudi ne samo za pripovedovanje zgodbe o razvoju bolezni, ampak za socialno integracijo posameznika $\mathrm{v}$ družbo $\mathrm{z}$ vsemi izkušnjami in povratnimi informacijami, ki jih tak posameznik ali posameznica prinese $\mathrm{v}$, družbo zdravih'. Ne gre samo za vzpostavljanje biografske kontinuitete človeka, obremenjenega s kronično boleznijo, ali za izogibanje stigmi, ampak za razširjanje družbenih meja strpnosti in sprejemanje drugačnosti. Ta 
proces se odvija na metaforični oz. diskurzivni, komunikacijski ravni.«(Ule, 2003: 89-90) Manjša slovenska raziskava (78 odraslih z diabetesom) potrjuje izjemno pomembno vlogo komunikacije med zdravstvenimi delavci in obolelimi, saj ta zmanjšuje občutek čustvenega stresa in izboljšuje občutek kakovosti življenja obolelih (Bahun, 2012).

Kako torej lahko pomagamo posamezniku pri osmišljanju življenja kljub kronični bolezni? Ali to pomeni, da bi bilo treba vse zdravstveno osebje usposobiti za psihoterapevtsko (npr. logoterapevtsko) pomoč? $\mathrm{Ne}$, nikakor ne. Če sklepamo iz sodobnih raziskav, zadostuje že sposobnost empatičnega komuniciranja, ki jo lahko opredelimo kot zmožnost razumevanja perspektive drugega, kadar je v stiski (Misra-Hebert, Isaacson, Kohn et al., 2012). Četudi gre pri empatiji za pretežno kognitivne zmožnosti vživljanja v položaj drugega (razumevanje izkušenj, skrbi in perspektiv druge osebe), pa ne smemo spregledati tudi čustvene »opore«, ki je največkrat pomembno gibalo akcij (samo)pomoči (Hoffmann, 2001). Raziskave kažejo, da stopnja empatije zdravnika do obolelega pomembno pozitivno vpliva na rezultate klinične slike oseb z diabetesom. Natančneje povedano, oboleli, katerih zdravniki so izražali visoko stopnjo empatije, so imeli bistveno boljši nadzor hemoglobina kot oboleli zdravnikov z nizko stopnjo empatije. Regresijska analiza (v katero so bile vključene še spremenljivke spol in starost zdravnikov in obolelih ter zdravstveno zavarovanje) je pokazala, da zdravnikova empatija svojstveno pripomore $\mathrm{k}$ napovedovanju optimalne klinične slike ljudi z diabetesom (Hojat, Louis, Markham, Wender, Rabinowitz, Gonella, 2011). »Le empatično komuniciranje nudi bolnikom možnost za delni nadzor nad medicinsko interpretacijo, intervencijo in odločitvami. Samo takšno komuniciranje v odnosu zdravnik-bolnik prepričljivo aktualizira čustvene, mentalne in duhovne komponente zdravilnega procesa in jim odpira prostor. Bistvena značilnost empatičnega zdravniškega komuniciranja je, da spoštuje avtonomijo in dostojanstvo bolnika.« (Ule, 2003: 137) Zavedati pa se moramo, da lahko tako empatijo kot komunikacijske sposobnosti izboljšamo s pomočjo kakovostnih vzgojno-izobraževalnih programov. Manjša raziskava vpliva vodenih vaj refleksivnega pisanja (šest srečanj) kaže, da takšen program lahko spodbudi razmislek in poveča sposobnost empatije med zdravniki (Misra-Hebert, Isaacson, Kohn et al., 2012).

Vloga zdravstvenega osebja pri posameznikovem soočanju s kronično boleznijo je torej izjemno pomembna. Nemalo pozornosti bi bilo treba nameniti pripravi zdravstvenovzgojnih programov, katerih temeljni namen ne bi smel biti akademsko poznavanje in razumevanje bolezni, zdravljenja in morebitnih dodatnih zdravstvenih posledic, marveč bi morali obolelim ponuditi zlasti pomoč pri prepoznavanju in razumevanju potrebnih sprememb $\mathrm{v}$ Pomembno je
obolele usposobiti
za samovodenje
kronične bolezni. njihovem vsakdanjem življenju ter jim dajati podporo pri razvoju samoučinkovitosti ob samovodenju svoje kronične bolezni. Pri izvajanju teh programov bi morala biti v ospredju problemsko poučevanje in metoda vodenega učnega pogovora, ki je usmerjen v iskanje oz. raziskovanje (Marentič Požarnik, Plut Pregelj, 2009). Še bolj kot sama metoda pa je pomembna zmožnost zdravstvenega osebja za empatično poslušanje in komunikacijo, ki bi jo bilo treba pri (bodočih) zdravstvenih delavcih sistematično razvijati. Raziskave namreč kažejo, da so za kakovostno delo zdravstvenih delavcev z 
obolelimi učinkoviti že krajši programi sistematičnega razvijanja komunikacijskih in empatičnih sposobnosti.

\section{KAJ LAHKO SKLENEMO NA PODLAGI PREDSTAVLJENEGA}

Kronična bolezen je za vsakega posameznika, njegove najbližje in tudi za celotno družbo zelo zahteven izziv, na katerega se v različnih družbenih kontekstih (ekonomskih, kulturnih, profesionalnih, zgodovinskih) različno odzovemo.

Zdravstvenovzgojno delo z ljudmi, ki se spopadajo s kroničnimi boleznimi, je vse prej kot enostavno, saj je cilj zlasti preoblikovanje že ustaljenih načinov življenja (prevzgoja) oz. oblikovanje novih, zdravstvenemu stanju bolj podpornih življenjskih slogov. Pri tem je povsem jasno, da še tako dobro poznavanje posebnosti same bolezni, njenega poteka in morebitnih zapletov, priporočenih načinov življenja, torej tradicionalno poučevanje, samo po sebi ni dovolj za potrebne spremembe življenjskega sloga in strategij obvladovanja bolezni. Prvi pogoj za to je posameznikova zmožnost sprejetja bolezni v svoje življenje ter prepoznavanje težav in ovir kot posledic bolezni, in ne nazadnje želja po učinkovitejšem obvladovanju simptomov. V tem procesu sprejemanja bolezni pa je izjemnega pomena zmožnost empatičnega komuniciranja zdravstvenega osebja, ki obolelemu pomaga pri iskanju smisla kljub trajni oviranosti in pri iskanju novega reda $\mathrm{v}$ življenju posameznika. Pri nadaljnjem, bolj strukturiranem izvajanju zdravstvenovzgojnega dela bi bilo treba izhajati zlasti iz konkretnih težav obolelih, skupno iskati za obolele relevantne rešitve in jih učiti strategij reševanj težav, če seveda želimo doseči čim večjo učinkovitost posredovanih strokovnih spoznanj in čim večjo motivacijo za njihovo aplikacijo v življenje posameznika.

Zdravstvenovzgojnemu delu z ljudmi, ki se spopadajo s kroničnimi boleznimi, bo v prihodnje treba nameniti nemalo pozornosti tudi $\mathrm{v}$ Sloveniji. Žal prepričljivi podatki o raznolikosti teh programov oz. pogostosti izvajanja niti o njihovi učinkovitosti niso na voljo. Vsekakor pa je spodbudno, da je letos objavljen kurikulum za vzgojno-izobraževalno delo z odraslimi sladkornimi bolniki (Kurikulum za edukacijo: o oskrbi odraslih bolnikov s sladkorno boleznijo, 2012). Pogled v vsebino pokaže, da se v okviru tega kurikuluma največ pozornosti namenja značilnostim različnih tipov sladkorne bolezni in spretnostim, potrebnim za obvladovanje bolezni na telesni ravni, prehranjevanju in gibanju ter posebnostim poteka bolezni $\mathrm{v}$ specifičnih življenjskih kontekstih. V programu žal ni zaslediti tem, kot so posameznikove potrebe na čustveni, socialni in duhovni ravni, na katere morajo oboleli za učinkovito samovodenje kronične bolezni prav tako odgovoriti. Sposobnostim empatičnega komuniciranja zdravstvenega osebja, razvijanja strategij reševanja težav in andragoškemu delu z obolelimi bomo morali v prihodnosti nameniti bistveno več pozornosti. Vsekakor pa bi te vsebine morale postati obvezne $\mathrm{v}$ dodiplomskih študijskih programih in tudi $\mathrm{v}$ programih izpopolnjevanja.

\section{LITERATURA}

Bahun, M. (2012). »Medsebojna pomoč in komunikacija kot del kakovosti življenja bolnikov s sladkorno boleznijo tipa 2 «. V: J. Klavs et al. (ur.), Naložba v preventivo se splača: zbornik predavanj. Ljubljana: Zbornica zdravstvene in babiške nege Slovenije - Zveza strokovnih društev medicinskih sester, babic in zdravstvenih tehnikov Slovenije, Sekcija medicinskih sester in zdravstvenih tehnikov v endokrinologiji. 
Bodenheimer, T., Lorig, K., Holman, H., Grumbach, K. (2002). »Patient self-management of chronic disease in primary care «. Journal of American Medical Association, 288: 2469-75 .

Bury, M., Newbould, J., Taylor, D. (2005). A rapid review of the current state of knowledge regarding lay-led self-management of chronic illness. London: National Institute for Health and Clinical Excellence.

Charmaz, K. (2000). »Experiencing chronic illness «. V: G. L. Albrecht, R. Fitzpatrick, S. C. Scrimshaw (ur.), The handbook of social studies in health \& medicine. London: Sage.

Davis, C. (2011). Current evidence for successful diabetes self-management support (SMS). Dostopno 30. 8. 2012 na strani: http://www.ihs. gov/MedicalPrograms/Diabetes/HomeDocs/ Training/WebBased/Seminars/Self_Mgmt_Support_handout_508c.pdf

Donaldson, L. (2003). »Expert patients usher in a new era of opportunity for NHS: The expert patient programme will improve the length and quality of lives «. British Medical Journal, 326: 1279-80.

Frankl, V. (1987). »Grundriß der Existenzanalyse und Logotherapie«. V: V. E. Frankl (ur.), Logotherapie und Existenzanalyse (Texte aus fünf Jahrzehnten). München: R. Piper.

Hoffman, M. L. (2001). Empathy and moral development: implication for caring and justice. Cambridge: Cambridge University Press.

Hojat, M., Louis, D. Z., Markham, F. W., Wender, R., Rabinowitz, C., Gonnella, J. S. (2011). »Physicians “ empathy and clinical outcomes for diabetes patients «. Acadademic Medicine, 86(3): 359-64.

Holman, H., Lorig, K. (2004). »Patient self-management: a key to effectiveness and efficiency in care of chronic disease «. Public Health Report, 19: 239-243.

Kleinman, A., Seeman, D. (2000). »Personal experience of illness«. V: G. L. Albrecht, R. Fitzpatrick, S. C. Scrimshaw (ur.), The handbook of social studies in health \& medicine. London: Sage.
Kurikulum za edukacijo: o oskrbi odraslih bolnikov s sladkorno boleznijo. (2012). Ljubljana: Zbornica zdravstvene in babiške nege Slovenije, Sekcija medicinskih sester in zdravstvenih tehnikov v endokrinologiji, Univerzitetni klinični center Ljubljana.

Marentič Požarnik, B., Plut Pregelj, L. (2009). Мoč učnega pogovora: Poti do znanja z razumevanjem. Ljubljana: DZS.

Misra-Hebert, A. D., Isaacson, J. H., Kohn, M., Hull, A. L., Hojat, M., Papp, K. K., Calabrese, L. (2012). »Improving empathy of Phisicians through guided reflective writing «. International Journal of Medical Education, 3: 71-77.

Nadgradnja zdravstvenega sistema do leta 2020. (2011). Ljubljana: Ministrstvo za zdravje. Dostopno 15. 10. 2012 na strani http://www.vlada.si/ fileadmin/dokumenti/si/projekti/2011/zdravstvena/ NADGRADNJA_ZDRAVSTVENEGA_SISTEMA_DO_LETA_2020_pdf_160211.pdf

Preventing chronic diseases : a vital investment. (2005). World Health Organisation global report, 2005. Dostopno 30. 8. 2012 na http://www.who. int/chp/chronic_disease_report/full_report.pdf

Taylor, D., Bury, M. (2007). »Chronic illness, expert patients and care transition «. Sociology of Health \& Illness, 29: 27-45.

Townsend, A. (2011). »Working to manage chronic illness in daily life«. Occupational therapy now, 13.5: 20-22.

Trstenjak, A., Ramovš, J. (1994). »Strokovni izrazi v logoterapiji«. V: V. E. Frankl (ur.), Zdravnik in duša: Osnove logoterapije in bivanjske analize. Celje: Mohorjeva družba.

Ule, M. (2003). Spregledana razmerja: O družbenih vidikih sodobne medicine. Maribor: Aristej.

1. Terciarna preventiva je preprečevanje ali vsaj zmanjševanje telesnih, duševnih in socialnih posledic že izražene bolezni z namenom, da bi vzpostavili stanje, kot je bilo pred začetkom bolezni, ali vsaj bliže prvotnemu stanju, oz. da bi posledice bolezni čim bolj omilili in ohranili posamezniku čim višjo stopnjo sposobnosti samostojnega življenja in funkcioniranja v skupnosti. 
2. Ponekod so razvili t. i. program bolnikov ekspertov (Expert Pacient Programme - EPP), ki kaže nekatere pozitivne rezultate pri zmožnosti samovodenja bolezni. Kritiki teh programov pa poudarjajo, da rezultatov ne gre posploševati, saj je populacija vključenih v programe specifična (notranje motivirani za čim višjo stopnjo obvladovanja kronične bolezni, bolj izobraženi, iz višjega socialno-ekonomskega sloja), in da bi morali te programe izvajati tako, da bi bili dostopni vsem osebam, ki se spopadajo s kronično boleznijo (več o tem Taylor, Bury, 2007).

\section{REHUMANIZACIJA MEDICINE (nem. Rehu-} manisierung der Medizin, angl. rehumanization of medicine) »Temeljna želja Viktorja Frankla, utemeljitelja logoterapije. Po njegovem mnenju je sodobna medicina manj potrebna psihologizacije svoje dejavnosti (da za razlago telesnih težav posameznega pacienta upošteva tudi njegove duševne težave), bolj pa je potrebna rehumanizacije - ponovnega počlovečenja svojih postopkov, tako da poleg telesnih in duševnih težav vidi tudi duhovne težave sodobnega človeka in poskuša biti pravična do njih. Samo celostna medicina, v kateri ni zapostavljena in zanemarjena nobena razsežnost človeškega bivanja, je lahko humana medicina.« (Trstenjak, Ramovš et al., 1994, str. 307)

4. VREDNOTE STALIŠČA (nem. Einstellungswerte, angl. attitudinal values) »So tisti del smiselne strukture stvarnosti, ki ga človek dojema in uresničuje kot osebni smisel s svojim osebnim stališčem do tragičnih in nespremenljivih zasukov usode: trpljenja, zmot, krivde in smrti, pa tudi smiselno stališče do lastnih zelo ugodnih življenjskih položajev, npr. bogastva, trdnega zdravja, velike nadarjenosti, slave in podobnega. Brez smiselnega stališča delujejo tako negativne tragične situacije kakor velika blaginja na človeka destruktivno. Za udejanjanje vrednot stališča so potrebni trden osebni sistem vrednot, notranja moč in zrelost, zavest o odgovornosti in globoko prepričanje, da ima življenje smisel in ga ohranja v vseh okoliščinah. Za uresničevanje teh vrednot je po Franklu odločilna človekova zmožnost za trpljenje (homo patiens). Ko jih uresničujejo stari, bolni, prizadeti ljudje in taki, ki jih je doletelo hudo trpljenje, s pokončno in pogumno držo, imajo socialni značaj dobrega zgleda.« (Trstenjak, Ramovš et al., 1994, str. 313-314) 